Ann. Biol. anim. Bioch. Biophys., 1979, 19 (5), 1547-1558.

\title{
The human antral follicle : Functional correlates of growth and atresia
}

\author{
par K. P. MCNATTY $\left({ }^{1}\right)$, Dianne MOORE SMITH, R. OSATHANONDH, K. J. RYAN \\ Laboratory of Human Reproduction and Reproductive Biology, Harvard \\ Medical School, 45 Shattuck Street, Boston, Massachusetts 02115 U. S. A.
}

\begin{abstract}
Summary. This communication reviews the current information on the developmental relationships between the various tissues of the growing human antral follicle. It also examines the various interrelationships between the hormone levels in antral fluid, the populations of granulosa cells, the steroidogenic capacities of thecal tissue and granulosa cells, and the status of the oocyte in antral follicles at different stages of growth or degeneration.

Healthy antral follicles are considered to be those containing an oocyte which appears healthy at the level of the dissecting microscope and more than 50 p. 100 of its full complement of granulosa cells at each follicle diameter. In follicles with more than 75 p. 100 of their full complement of granulosa cells, 'at a given follicle diameter, the endocrine microenvironment is one that is enriched with FSH and cestradiol. Follicles with between 51 and 75 p. 100 of their full complement of granulosa cells at a given follicle diameter are invariably undergoing degenerative changes and their endocrine microenvironment is deficient in FSH and ostradiol but rich in androgen. However, it is believed that many of these follicles are still capable of being recruited back into the pool of healthy growing follicles. Atretic antral follicles are considered to be those undergoing irreversible degenerative changes: they usually contain $<50$ p. 100 of their maximum number of granulosa cells and a degenerating oocyte. In atretic follicles, the endocrine microenvironment is deficient in FSH and œstradiol but contains levels of androstenedione comparable to those in healthy follicles.
\end{abstract}

The functional capacities of granulosa cells and thecal tissue from healthy follicles differ from those of atretic follicles. In vitro, granulosa cells from healthy follicles have the capacity to produce large amounts of cestradiol and smaller amounts of androstenedione and these estrogen-secreting cells retain the capacity to undergo mitosis in culture. By contrast, granulosa cells from atretic follicles do not have the capacity to produce much cestradiol although they remain steroidogenically competent for some time since they continue to synthesize androgens. In vitro, these cells are incapable of mitotic activity or of maintaining their population. In vitro, thecal tissue from both healthy and atretic follicles produces large amounts of androstenedione. In addition, thecal tissue from healthy but not atretic follicles produces some œstradiol.

The amount of degeneration of the oocyte in vivo and the subsequent maturational capabilities of the oocyte in vitro are correlated with the number of granulosa cells present and also with the levels of steroids in antral fluid. When healthy-looking oocytes were recovered from follicles with $\leqslant 50 \mathrm{p} .100$ of their granulosa cells and/or had been exposed to high levels of androgen compared to cestrogen in vivo, their potential for meiotic matura-

${ }^{(1)}$ Present address : Wallaceville Animal Research Centre, Private Bag, Upper Hut, New Zealand. 
tion in vitro was severely reduced compared to oocytes from follicles with $>50$ p. 100 of their full complement of granulosa cells and low androgen/œstrogen ratios.

It is suggested that the uninterrupted development of a human antral follicle is dependent upon its granulosa cells sustaining an œstrogen-enriched micro-environment within the follicle and its thecal envelope retaining the capacity to produce cestradiol as well as androstenedione.

\section{Introduction.}

A characteristic feature of the human ovary during the menstrual cycle is the presence of antral follicles in various stages of development or atresia. Of those antral follicles capable of further maturation, only one goes on to ovulate during each cycle. Most of the remaining antral follicles do not mature into ovulatory follicles but undergo degenerative changes at some earlier stage of their development. Despite the high incidence of follicular atresia in the human ovary relatively little is known about the functional status of follicles undergoing degenerative changes or how they differ from the population which have the potential for further development.

This communication reviews the current information on the developmental relationships between the various tissues of the developing human antral follicle. If then examines the various interrelationships between hormone levels in antral fluid, granulosa-cell numbers, the steroidogenic capacities of thecal tissue and granulosa cells, the status of the oocyte in antral follicles at different stages of growth or degeneration, and the potential of these oocytes for nuclear maturation in vitro. It is suggested that these data may help to provide a functional basis by which to assess the developmental status of the human antral follicle.

\section{Developmental relationships between the various tissues of the growing human follicle.}

The non-growing primordial follicle in women is about $0.05 \mathrm{~mm}$ in diameter (Baker, 1963). It consists of a primary oocyte in prophase of the first meiotic division together with a single layer of spindle-shaped cells which are the undifferentiated granulosa cells. The oocyte-granulosa cell complex is separated from the surrounding stromal tissue by a basement membrane. Once this follicle starts to grow, its spindleshaped granulosa cells become cuboidal and then undergo successive mitotic divisions. Coincident with granulosa-cell proliferation, fluid-filled spaces form between the cells. Also, at this time, some of the adjacent stromal cells outside the basement membrane become orientated in concentric perifollicular layers (for review see Ross and Vande Wiele, 1974). It has been suggested that the organization of the cells outside the follicle is regulated by the granulosa cells (Dubreuil, 1957). However, at present, there is no evidence to support this hypothesis. Just before antrum formation, the human follicle is about $0.2 \mathrm{~mm}$ in diameter and it contains 4 to 5 layers of granulosa cells. At this stage of follicular development the thecal compartment is about $0.02 \mathrm{~mm}$ in thickness. The cells of the thecal compartment are much less uniform in size compared to the membrana granulosa although some of them are comparable in diameter (i.e., $\sim 5$ to $6 \mu \mathrm{m}$ ). As the follicle enlarges beyond $0.2 \mathrm{~mm}$, granulosa cells 
continue to proliferate and the accumulating fluid in the extracellular spaces coalesce to form the antrum. Little is known about the speed with which this event takes place, however most follicles have a fully developed antrum by the time the follicle has reached a diameter of $0.4 \mathrm{~mm}$. The organization of the granulosa cells in order to form the antrum appears to be regulated by FSH and estradiol. In the hypophysectomized, immature female rat, addition of FSH alone does not stimulate follicular growth or antrum formation, whereas œstrogen alone induces granulosa cell proliferation without the formation of an antrum. Addition of FSH together with œstrogen induces granulosa cell proliferation together with the concurrent development of a fluid-filled antrum (Goldenberg et al., 1972). In the human, the development of the follicle after antrum formation is associated with concomitant increases in its thecalcell mass, granulosa-cell number and antral-fluid volume (fig. 1). When the human follicle has reached a diameter of $\sim 4 \mathrm{~mm}$, its thecal envelope is about $0.12 \mathrm{~mm}$ in thickness and has an average wet weight of about $28 \mathrm{mg}$. In addition, some of the largest cells in this tissue have increased in diameter from 5 to $6 \mu \mathrm{m}$ to about $12 \mu \mathrm{m}$. At this time, the follicle has accumulated about 1 million granulosa cells and about $30 \mu \mathrm{l}$ of antral fluid. Healthy follicles may continue to enlarge beyond $4 \mathrm{~mm}$ to reach a diameter of about $25 \mathrm{~mm}$. There is insufficient information available on the thecal envelope of large follicles to draw conclusions about its properties. In two follicles, with a diameter of $\geqslant 20 \mathrm{~mm}$, the thecal envelope averaged only about $0.15 \mathrm{~mm}$ in cross-section suggesting that this layer increases only slightly in thickness as the follicle enlarges from $4 \mathrm{~mm}$ to $\geqslant 20 \mathrm{~mm}$. Nevertheless, the totcl mass of thecal tissue increases as the follicle develops beyond $4 \mathrm{~mm}$ in diameter (fig. 1). Some of the cells in

FIG. 1. - Relationship between follicle diameter, the maximum number of granulosa cells, and the average wet weight of thecal tissue at each follicle diameter.

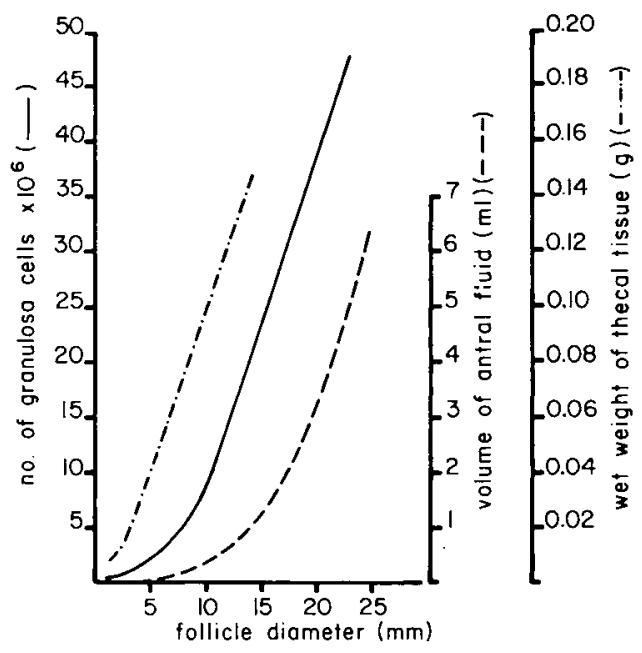

the thecal envelope of large follicles: $\geqslant 15 \mathrm{~mm}$ diam.) increase in diameter to about $25 \mu \mathrm{m}$. With the exception" of the oocyte, these are the largest cells present in the follicle at this time. It appears that as the antral follicle develops, the thecal envelop increases in mass and some of its cells increase considerably in diameter. The tissue per se, however, apparently does not increase substantially in thickness. Within the basement membrane of the largest healthy antral-follicles, (i.e., $\geqslant 20 \mathrm{~mm}$ in diame- 
ter), there are between 40 and 50 million granulosa cells and up to $6.5 \mathrm{ml}$ of antral fluid. The greatest accumulation of fluid occurs during the final stages of follicle maturation. For example, as the follicle increases in diameter from $20 \mathrm{~mm}$ to $25 \mathrm{~mm}$ the granulosa-cell number increases by 20 p. 100. During this time, however, its fluid volume increases by about 200 p. 100 , i.e., from $\sim 3.2 \mathrm{ml}$ to $6.5 \mathrm{ml}$ (fig. 1). In large antral follicles, granulosa cells are much less uniform in size. Those cells closest to the basement membrane are larger than those nearest the follicular antrum. The largest granulosa cells are about $20 \mu \mathrm{m}$ in diameter which is close to the diameter of a luteal cell $(\sim 25 \mu \mathrm{m})$. Even some of the cells furthest away from the membrane are larger than they were at an earlier stage of development since their diameters may range up to $12 \mu \mathrm{m}$. Thus, within the basement membrane of the enlarging antral follicle during its growth phase, there is a substantial increase in fluid volume, an overall increase in the size of many of the granulosa cells as well as an increase in the granulosa-cell number.

At the onset of the follicular phase, the largest human follicle with its full complement of granulosa cells, is about $4 \mathrm{~mm}$ in diameter. Such a follicle has increased $80-$ fold in diameter and accumulated about 1 million granulosa cells since it started to grow. Thus, the follicle which goes on to ovulate probably starts its growth long before the onset of the follicular phase in which it will ovulate. At the end of the follicular phase, the largest healthy follicle may reach a diameter of $25 \mathrm{~mm}$. It is therefore apparent that the follicular phase of the menstrual cycle is associated with the relatively late stages of maturation of the ovulatory follicle. Indeed, the length of the follicular phase may be determined by the hormonal secretions from this follicle as it develops from a $4 \mathrm{~mm}$ structure to its final stage of maturation.

\section{The endocrine microenvironment of healthy antral follicles.}

The endocrine microenvironment of a human antral follicle is profoundly influenced by the number of granulosa cells present (table 1). If a healthy antral follicle is defined as that follicle with a healthy-looking oocyte and with $>75$ p. 100 of the maximum number of granulosa cells possible for the diameter it has reached, the endocrine milieu of the antral fluid is characteristic for that type of follicle. It contains detectable levels of FSH $(>1.5 \mathrm{mlU} / \mathrm{ml}$ and high levels of cestradiol $(>1 \mu \mathrm{g} / \mathrm{ml})$ while androstenedione as well as progesterone, testosterone, dihydrotestosterone and œstrone are present at much lower concentrations (table 1 ; see McNatty and Baird, 1978 ; McNatty et al., 1979a). Follicles might also be considered to be healthy, if they contain an oocyte that is not degenerating, and between 51 and 75 p. 100 of their full complement of granulosa cells per follicle diameter. However, these follicles no longer contain detectable levels of FSH and their levels of cestradiol have declined sharply while those of androstenedione remain unchanged. Although these follicles no longer have an œstrogenic microenvironment, their granulosa cells can be stimulated in vitro to aromatise androstenedione to œstradiol in the present of FSH (McNatty, unpublished data). Presumably therefore, some of these follicles could be rescued from further degeneration and recruited back into the pool of healthy growing follicles when stimulated with a gonadotrophin preparation rich in FSH-activity. 


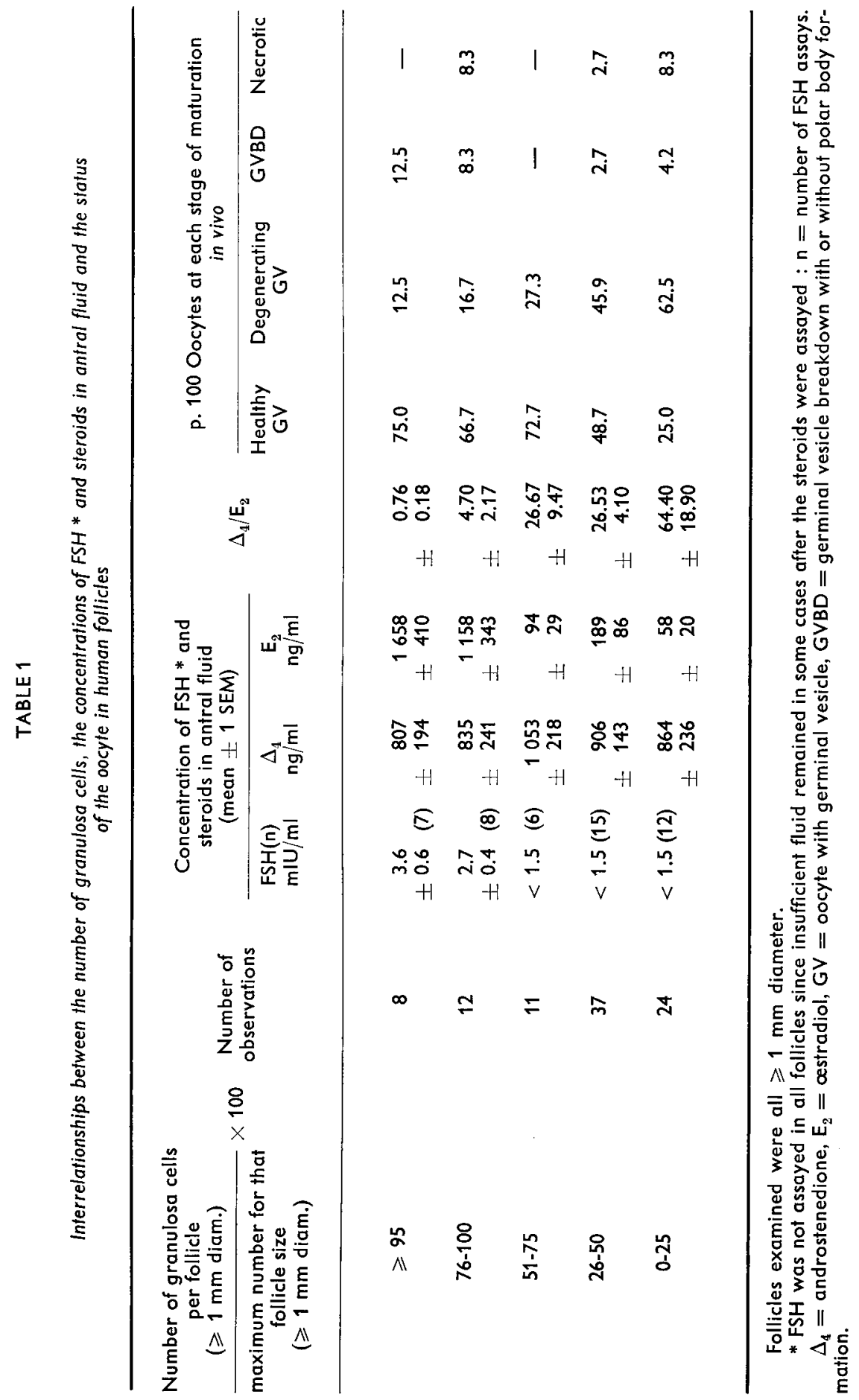


In summary, the endocrine microenvironment of the healthiest antral follicle is one which is enriched with FSH and œstrogen and has the lowest levels of androgen. A progressive reduction in the number of granulosa cells is associated with a simultaneous reduction in the level of œstrogen and FSH and with a reduced probability of recovering a morphologically normal-looking oocyte or of recovering one that is likely to complete the process of nuclear maturation in vitro.

\section{The endocrine microenvironment in atretic follicles.}

An antral follicle may be considered to be undergoing irreversible degenerative changes when it has less than 50 p. 100 of its full complement of granulosa cells. Many of the healthy-looking oocytes from these follicles, when cultured, are unable to resume meiosis (McNatty et al., 1979a). Moreover, in these follicles, the level of cestradiol is less than 20 p. 100 of that in follicles with their full complement of granulosa cells and the level of androgen is many-fold higher than that of œstrogen (table 1). Also, granulcsa cells from many of these degenerating follicles are incapable of metabolizing androstenedione to cestradiol when exposed to FSH (McNatty, unpublished data). Therefore, these follicles are unlikely to recover from their degenerative state since they no longer have cells with the capacity to enrich the follicular microenvironment with œstrogen (McNatty and Baird, 1978).

Irrespective of the criteria used to assess follicular atresia, most follicles which show degenerative changes still contain high levels of steroid similar to the levels in healthy follicles (table 1). However, degenerating follicles invariably have low levels of œstrogen and FSH and a level of androgen which exceeds that of œstrogen.

\section{Steroid production by thecal tissues and granulosa cells from healthy and atretic antral follicles.}

In tissue culture, both granulosa cells and thecal tissues from human follicles have the capacity to produce progestins, androgens and ostrogens (McNatty et al., 1979b). However, the pattern of steroid production by the two cell-types differ (figs. $2 a$, b). Moreover, even for each cell-type, the pattern of steroids produced differs according to whether the cells or tissues were harvested from healthy follicles ( $>50$ p. 100 of their maximum number of granulosa cells) or atretic follicles ( $\leqslant 50$ p. 100 of their maximum number of granulosa cells) (figs. $2 a, b$ ).

Granulosa cells from healthy follicles, irrespective of follicle-size or stage of cycle, produce de novo 5- to 100-times more œstrogen than that produced by cells from atretic follicles. Moreover, they produce more œstradiol than androstenedione. It seems that throughout most stages of antral follicle growth, granulose cells have the capacity for de novo synthesis of œstradiol. By contrast, during follicular atresia, granulosa cells lose their capacity to synthesize œstrogen but not androgen. They therefore dedifferentiate from an cstrogenic state into an androgenic one.

Irrespective of the developmental status of the follicle, granulosa cells are incapable of producing very much progesterone in vitro unless the cells are recovered from a healthy follicle during the late follicular phase (fig. $2 a$ ). These enlarged cells show 
morphological characteristics similar to those of luteal cells and they are fully co mpetent to secrefe progesterone in response to LH stimulation (Baird et al., 1975 ; McNatty, 1979).
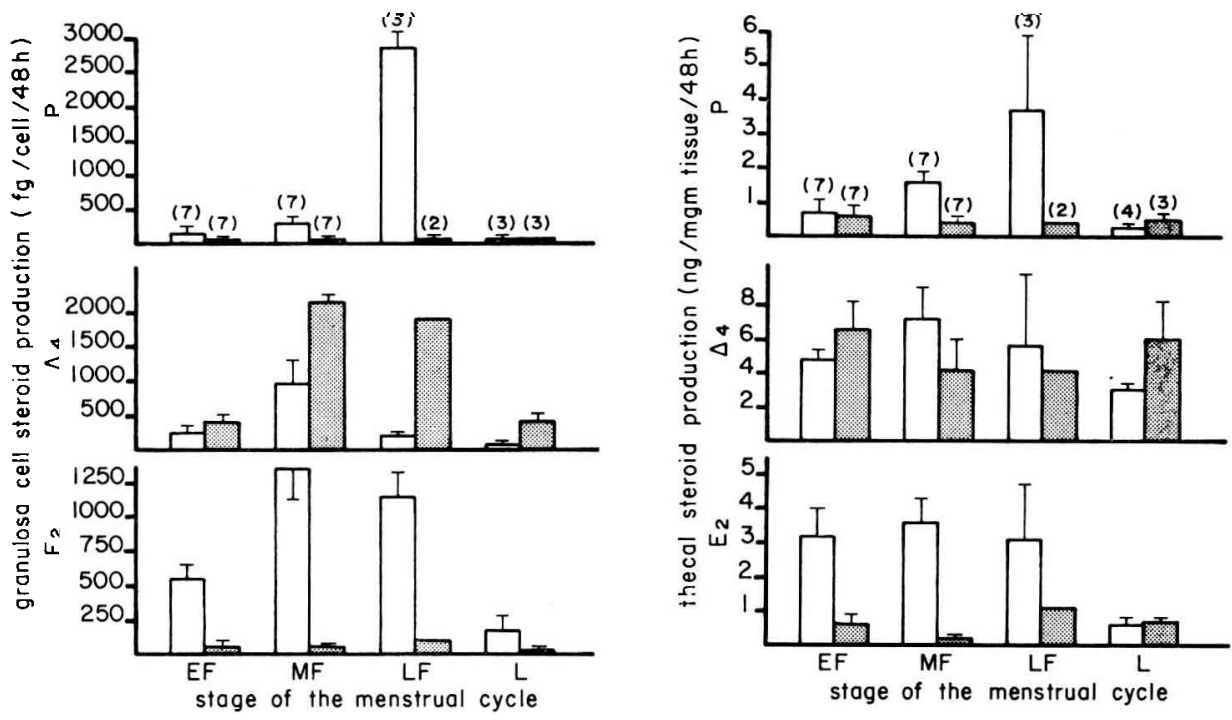

FIG. 2. - The production of progesterone, androstenedione, and œestradiol by granulosa cells (fig. 2a) and thecal tissue (fig. 2b) harvested from healthy and atretic follicles at different stages of the menstrual cycle. Data for healthy follicles is shown by the white histograms. Data for atretic follicles is shown by the black histograms. Healthy follicles were those containing $>50$ p. 100 of their maximum granulosa-cell number. Atretic follicles were those containing < 50 p. 100 of their maximum granulosacell number. Hormone production was that amount accumulated in the culture medium after $48 \mathrm{~h}$ culture minus the amounts presented in the tissue and medium at the start of culture. EF, MF LF refer to early, mid - and late follicular phase while $L$ refers to luteal phase. All values are expressed by means \pm 1 SEM.

Throughout most stages of antral follicle development it seems that granulosa cells may be present in one of two functionally differentiated states. The functional status of granulosa cells determines whether the endocrine microenvironment of the follicle is « œstrogenic\}》 or «fandrogenici》 since these cells account for about 90 p. 100 of the cstradiol and between 30 and 80 p. 100 of the androgen in antral fluid (McNatty and Baird, 1978 ; McNatty ef al., 1979c). Moreover, the functional status of granulosa cells influences their level of mitotic activity. A granulosa cell suspension with the capacity to enrich its in vitro environment with œstrogen increases its population during culture. By contrast, a granulosa cell suspension with the capacity to enrich its in vitro environment with androgen is unable to increase its cell number or even maintain its existing population during long-term culture (McNatty ef al., 1979b).

Thecal tissue in vitro is primarily a source of androstenedione and to a lesser extent of cstradiol. The capacity of thecal tissue from healthy follicles to produce androstenedione is comparable to that from atretic follicles. The functional capacity 
of thecal tissue in healthy follicles differs from that in atretic follicles in its capacity to produce cestrogen : thecal tissue from healthy follicles produces relatively large amounts of œstradiol compared to that produced by tissue from atretic follicles (fig. $2 b$ ).

It would seem that a healthy follicle is one which contains granulosa cells with the de novo capacity to produce œstradiol and a thecal envelope with the capacity to produce œstradiol as well as androstenedione. Furthermore, it is suggested that a follicle in its irreversible stages of atresia is one which contains both granulosa cells and thecal tissue with the capacity to produce androgens but not cestrogens.

\section{The relationship between hormone levels in antral fluid and oocyte matura- tion in vivo and in vitro.}

The hormonal milieu of antral fluid is correlated with the viability of the oocyte in vivo (table 1). Morphologically normal oocytes with a germinal vesicle were most frequently obtained from follicles with a high level of œstradiol or were presumed to have recently had high levels of this hormone in antral fluid (table 1). By contrast, degenerating oocytes were more frequently obtained from follicles which had been « androgenic 》 for some period of time. It seems that the amount of oocyte degeneration is dependent on both the number and the funcrional status of its adjacent granulosa cells. Apparently, the oocyte is not threatened until the level of cestrogen has been about 25 -fold lower than that of androgen for a certain period of time. This degree of androgen exposure occurs after the follicle has lost more than 50 p. 100 of its granulosa cells. In the majority of follicles, it appears that functional changes in the

TABLE 2

Relationships between the ability of humon oocyfes * to resume meiosis in vifro, the size of the oocyfe and the concentrations of androstenedione and cestradiol in antral fluid

\begin{tabular}{|c|c|c|c|c|c|}
\hline $\begin{array}{l}\text { Oocyte status } \\
\text { after } 48 \mathrm{hrs} \\
\text { in culture }\end{array}$ & $\begin{array}{c}\text { Number of } \\
\text { observations } \\
n\left(n^{1}\right)\end{array}$ & $\begin{array}{c}\text { Oocyte } \\
\text { diameter } \\
(\mu \mathrm{m})\end{array}$ & $\begin{array}{c}\text { Steroid concentro } \\
\text { Androstenedione } \\
\qquad\left(\Delta_{4}\right)\end{array}$ & $\begin{array}{l}\text { tion in antral } \\
\text { Oestradiol } \\
\left(E_{2}\right)\end{array}$ & $\begin{array}{l}\text { uid }(\mathrm{ng} / \mathrm{ml}) \\
\qquad \Delta_{4} / E_{2}\end{array}$ \\
\hline GV & 14 (19) & $\begin{array}{c}108.2(a) \\
\pm 0.9\end{array}$ & $\begin{array}{r}825 \\
\pm 220\end{array}$ & $\begin{aligned} & 106 b \\
\pm & 79\end{aligned}$ & $\pm 3^{11(d)}$ \\
\hline GVBD & $11(14)$ & $\begin{array}{l}110.6 \\
\quad \pm 2.3\end{array}$ & $\begin{array}{r}1183 \\
\pm 320\end{array}$ & 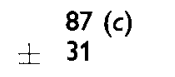 & $\begin{aligned} & 40(d e) \\
\pm & 13\end{aligned}$ \\
\hline PB & $11(10)$ & $\begin{array}{c}117.2(a) \\
\quad \pm 2.2\end{array}$ & $\begin{array}{r}876 \\
+178\end{array}$ & $\begin{array}{r}1019(b c) \\
\pm 300\end{array}$ & $\begin{array}{r}11(\mathrm{e}) \\
\pm \quad 5\end{array}$ \\
\hline Necrotic & $1(2)$ & $\begin{array}{l}95.5 \\
\pm 4.5\end{array}$ & 473 & 12 & 39 \\
\hline
\end{tabular}

(*) Data presented is for germinal vesicle stage oocytes which appeared free of degeneration at the level of the dissecting microscope $(\times 100)$. All values are expressed as means or means \pm SEM. $\mathrm{GV}=$ oocyte with germinal vesicle, GVBD = oocyte that underwent germinal vesicle breakdown but did not form a polar body, PB = oocyte with polar body, $n=$ number of steroid measurements, $\mathrm{n}^{1}=$ number of oocyte measurements, $a, b, c, d, \mathrm{e}=$ all $\mathrm{p}<0.02$. 
steroidogenic capacity of granulosa cells and/or thecal tissue normally precede any visible degenerative changes in the oocyie (McNatty ef al., 1979a).

Only 53 p. 100 of the oocytes that appeared free of degeneration in vivo were capable of resuming meiosis and/or completing the first meiotic division in vitro (table 2). The behaviour of healthy-looking oocytes in vitro was correlated with their diameter and the level of cstradiol and androstenedione in antral fluid (table 2). Provided the oocyte had a diameter ranging between 115-120 $\mu \mathrm{m}$ and was bathed in a fluid with high œstrogen levels relative to those of androgen, it was capable of resuming meiosis and forming a polar body after being removed from the follicular environment and cultured for 48 hrs. By contrast, oocytes not significantly different in diameter $(108-113 \mu \mathrm{m})$ which were bathed in a fluid, with low œestrogen levels relative to androgen, were capable of undergoing germinal vesicle breakdown but not forming a polar body in vitro (table 2). Oocytes significantly smaller $(107-109 \mu \mathrm{m})$ than those which formed polar bodies but exposed to the same androgen/œstrogen ratio $\left(\Delta_{4} / E_{2}=11\right)$ were unable to resume meiosis and retained their nuclei throughout the culture period. Two oocytes harvested from a highly-androgenic fluid environment were unable to recover in vitro and underwent necrotic changes.

Little is known concerning the regulation of oocyte maturation within the developing follicle. The present results indicate that the oocyte must grow to a certain diameter before it is competent to undergo nuclear maturation. These data confirm, in the human, the correlation between oocyte diameter and capacity to resume meiosis described for hamsters (Iwamatsu and Yanagimachi, 1975) and mice (Sorensen and Wassarman, 1976). The present data also show that a follicular environment relatively rich in œstrogen is required to maintain the oocyte in a morphologically normal condition and to permit the healthy-looking, fully-grown germinal vesicle-stage oocyte to undergo nuclear maturation in culture. These results are in agreement with Hunter, Cook and Baker (1976) for pigs, Moor (1978) for sheep, Smith, Conaway and Kerber (1978) for rhesus monkeys and Smith and Tenney (1978) for hypophysectomized mice.

It has also been suggested that a non-steroidal substance in antral fluid of several species, including man, prevents the oocyte from resuming meiosis in vivo before the ovulatory LH surge (Channing and Tsafriri, 1978 ; Tsafriri, Pomerantz and Channing, 1976 ; Hillensjö ef al., 1978). If this were the only factor important in regulating the resumption of meiosis, the removal of similar-sized human oocytes from their follicular environment should have resulted in similar rates of polar body formation in vitro regardless of the steroid concentration in the antral fluid. The present data, and those of others, suggest that oocytes from follicles with the highest concentrations of œstrogens relative to androgens have the greatest potential for nuclear maturation in culture. Thus, nuclear maturation in vivo is probably not turned off or on simply by the presence or absence of a protein inhibitor but is likely to be much more finely luned by the endocrine status of the follicle cells before the $\mathrm{LH}$ stimulation of the resumption of meiosis in preovulatory oocytes.

\section{Conclusions.}

The development of the human antral follicle is associated with concomitant increases in the mass of its thecal envelope, in the number of its granulosa cells and in 
its antral-fluid volume. Also during development, the steroid-producing cell-types of the follicle, undergo varying degrees of enlargement. During follicle growth, the mitotic activity of granulosa cells and the viability of the oocyte are dependent upon the granulosa cells retaining their capacity to enrich the follicular microenvironment with œstrogen. The cells are only able to maintain this functional status if FSH is present within the follicle. In the absence of $\mathrm{FSH}$, granulosa cells lose their capacity to produce cstrogen and they dedifferentiate into functionally competent androgensecreting cells. This loss in aromatase activity by granulosa cells is associated with a similar loss in the thecal tissues.

At the same time oocytes undergo a reduction in maturational capacity or begin to degenerate. Therefore, the uninterrupted development of a human antral follicle appears to be critically dependent on the presence of FSH in antral fluid and on the thecal and granulosa cells retaining the capacity to produce cestradiol.

EEC Seminar on « Ovarian stimulation and egg quality in mammals », Luynes, France, octobre 1978.

Acknowledgements. - We wish to thank Ms. Roberta Todd for measuring FSH in antral fluid and Dr. Anastasia Makris and Mr. Camillio de Grazia for assisting with the steroid assays in culture media and human antral fluid. We also wish to thank Ms. Denise Lung for the typing of this manuscript. Dr. K. P. McNatty is a recipient of a Harkness Fellowship from the Commonwealth Fund of New York. This research was supported by Public Health Service Grants Nos HD06916, HD07923, HD06645.

Résumé. Ce rapport analyse les informations actuelles relatives à l'interaction des divers tissus du follicule antral humain au cours de son développement. Il examine également les diverses corrélations qui existent entre les taux d'hormones dans le fluide folliculaire, les populations de cellules de la granulosa, les capacités stéroïdogènes du tissu thécal et des celiules de la granulosa, ainsi que l'état de développement de l'ovocyłe à chaque étape de la croissance ou de la dégénérescence des follicules à antrum.

Le bon état des follicules à antrum est jugé d'après l'éfat de leur ovocyte et par la présence de plus de 50 p. 100 du nombre normal de cellules de la granulosa pour chaque taille folliculaire. Pour les follicules renfermant plus de 75 p. 100 du nombre normal de cellules de la granulosa, le micro-milieu endocrinien est riche en FSH et en cstradiol. Les follicules contenant de 51 à 75 p. 100 de leur nombre final de cellules de la granulosa sont normalement destinés à dégénérer et leur micro-milieu endocrinien est appauvri en FSH et en cestradiol, mais riche en androgènes. Il semble cependant que beaucoup de ces follicules puissent encore être réintroduits dans le pool des follicules sains en croissance. Sont considérés comme follicules antraux atrétiques ceux qui subissent des changements dégénératifs irréversibles : ils renferment généralement moins de 50 p. 100 de leur taux maximal de cellules de la granulosa et possèdent un ovocyte dégénéré. Le micro-milieu endocrinien de ces follicules atrétiques est pauvre en FSH et en œstradiol, mais contient des taux d'androstènedione comparables à ceux des follicules non atrétiques.

Les capacités fonctionnelles des cellules de la granulosa et du tissu thécal des follicules sains diffèrent de celles des follicules atrétiques. In vitro les cellules de la granulosa des follicules sains peuvent produire de grandes quantités d'œstradiol et des quantités moindres d'androstènedione : in vitro ces cellules sécrétrices d'œstrogène peuvent se diviser en culture. Au contraire, les cellules de la granulosa des follicules atrétiques ne peuvent produire une grande quantité d'œestradiol, bien qu'elles conservent leur aptitude stéroïdogène pendant un certain temps, puisqu'elles synthétisent des androgènes. In vitro ces cellules n'ont 
plus d'activité mitotique ef leur nombre décroît. In vitro le tissu thécal provenant des follicules atrétiques ou non, fabriquent de grandes quantités d'androstènedione. Seul le tissu thécal provenant de follicules non atrétiques produit de l'œtradiol.

La résistance de l'ovocyte in vivo et sa capacité à effectuer sa maturation in vitro dépendent du nombre de cellules de la granulosa présentes dans le follicule ainsi que des taux de stéroïdes folliculaires. Des ovocytes apparemment sains, mais provenant de follicules contenant moins de 50 p. 100 du nombre normal de celfules de la granulosa et/ou qui ont été exposés in vivo à des taux élevés d'androgènes et de faibles taux relatifs d'œstrogène, s'avèrent incapables de reprendre leur méiose in vitro et de former leur globule polaire à un taux comparable à celui d'ovocytes provenant de follicules contenant plus de 50 p. 100 de la population normale de cellules de la granulosa et soumis à un faible rapport androgènes/oestrogènes.

Nous suggérons que, pour qu'un follicule à antrum humain se développe de manière ininterrompue, les cellules de la granulosa doivent maintenir un micro-milieu intrafolliculaire riche en œstrogène ef la thèque doit être capable de produire de l'œstradiol en même temps que de l'androstènedione.

\section{References}

BAIRD D. T., BAKER T. G., McNATTY K. P., NEAL P., 1975. Relationship between the secretion of the corpus luteum and the length of the follicular phase in the ovarian cycle. J. Reprod. Fert., 45, 611-619.

BAKER T. G., 1963. A quantitative and cytological study of germ cells in human ovaries. Proc. roy. Soc. B, 158, 417-433.

CHANNING C. P., TSAFRIRI A., 1978. Regulations of ovulatory processes : Ovum maturation, follicular rupture and luteinization. In SADLER, W. A., SEGAL S., Advances in fertility regulation through basic research, Plenum Press, New York.

DUBREUIL G., 1957. Le déterminisme de la glande thecale de l'ovaire. Induction morphogène à partir de la granulosa folliculaire. Acta anat., 31, 269-274.

GOLDENBERG R. L., VAITUKAITIS J. L., ROSS G. T., 1972. Esirogen and follicle-stimulating hormone interactions on follicle growth in rats. Endocrinology, 90, 1492-1498.

HILLENSJÖ T., BATTA S. K., KRIPNER A. S., WENTZ A. C., SULEWSKI J., CHANNING C. P., 1978. Evidence for an oocyte maturation inhibitor in human follicular fluid. Endocrinology, 102, A 256.

HUNTER R. H. F., COOK B., BAKER T. G., 1976. Dissociation of response to injected gonadotropin between the Graafian follicle and oocyte in pigs. Nature, Lond., 260, 156-158.

IWAMATSU T., YANAGIMACHI R., 1975. Maturation in vitro of ovarian oocytes of prepubertal and adult hamsters. J. Reprod. Fert., 45, 83-90.

MCNATTY K. P., 1979. Follicular deferminants of corpus luteum function in the human ovary. In CHANNING C. P., MARSH J. M., SADLER W. A., Ovarian follicular and corpus luteum function, Plenum Press, New York, 465-481.

MCNATTY K. P., BAIRD D. T., 1978. Relationship between follicle-stimulating hormone, androstenedione and ostradiol in human follicular fluid. J. Endocrin., 76, 527-531.

McNATTY K. P., MAKRIS A. M., DE GRAZIA C., OSATHANONTH R., RYAN K. J., 1979b. The production of progesterone, androgens and estrogens by granulosa cells, thecal tissue and stromal tissue from human ovaries in vitro. J. Endocrin. Metab. (in press).

MCNATTY K. P., MAKRIS A., DE GRAZIA C., OSATHANONDH R., RYAN K. J., 1979c. The production of progestins, androgens and oestrogens by human granulosa cells in vivo and in vitro. J. Steroid Biochem. (Submitted for publication).

MCNATTY K. P., MOORE-SMITH D., MAKRIS A., OSATHANONDH R., RYAN K. J., 1979a. The microenvironment of the human antral follicle : Interrelationships between the steroid levels in antral fluid, the population of granulosa cells and the status of the oocyfe. J. Endocrin. Metab. (in press). 
MOOR R. M., 1978. Role of steroids in the maturation of ovine oocytes. Ann. Biol. anim. Biochem. Biophys., 18, 477-482.

ROSS G. T., VANDE WEILE, R. L., 1974. The ovaries, Chapter 7. In WILLIAMS R. H., Textbook of endocrinology, 5th Ed., W. B. Saunders and Co., London.

SMITH D. M., CONAWAY C. H., KERBER W. T., 1978. ' Influences of season and age on maturation in vitro of rhesus monkey oocytes. J. Reprod. Fert., 54, 91-95.

SMITH D. M., TENNEY D. Y., 1978. Effect of hypophysectomy on mouse oocyte maturation in vitro. J. Reprod. Fert. (in press).

SORENSEN R. A., WASSARMAN P. M., 1976. Relationship between growth and meioticj maturation of the mouse oocyte. Devel. Biol., 50, 531-536.

TSAFRIRI A., POMERANTZ S. H., CHANNING C. P., 1976. Inhibition of oocyte maturation by porcine follicular fluid : partial characterization of the inhibitor. Biol. Reprod., 14, 511-516. 